\title{
Allicin, a SUR2 opener: possible mechanism for the treatment of diabetic hypertension in rats
}

\section{Harikesh Dubey, ,1 Anamika Singh, ${ }^{2}$ Angad Mohanrao Patole, ${ }^{1}$ Chandrashekhar Ramdas Tenpe, ${ }^{1}$ Balu Vinayak Ghule ${ }^{1}$}

${ }^{1}$ Institute of Pharmaceutical Education and Research, India, ${ }^{2}$ Department of Pharmaceutical Sciences, Raj Kumar Goel Institute of Technology, India.
Revista Brasileira de Farmacognosia Brazilian Journal of Pharmacognosy 22(5): 1053-1059, Sep./Oct. 2012

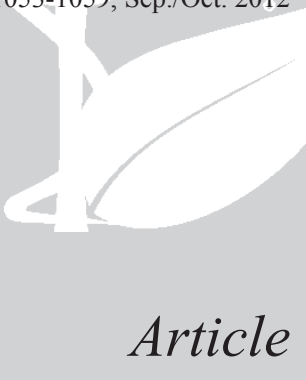

Received 3 Nov 2011

Accepted 19 Jan 2012

Available online 12 Apr 2012

Keywords: Allicin diabetic hypertension hyperpolarizing streptozotocin sulfonylurea receptor vasodilator

ISSN 0102-695X http://dx.doi.org/10.1590/S0102$695 \times 2012005000046$

\section{Introduction}

Diabetes mellitus (DM) represents a spectrum of metabolic disorders, becomes a major health challenge worldwide (Moore et al., 2009). Cardiovascular disease is the leading cause of mortality (52\% of deaths) in individuals with DM (Aminot Gilchrist \& Anderson, 2004). Hypertension is an extremely common co morbid condition in DM, affecting about $20-60 \%$ of patients with diabetes (Sydow et al., 2005; Wilhelm et al., 2007; Shin \& Chung, 2009).

The ATP sensitive potassium $\left(\mathrm{K}_{\mathrm{ATP}}\right)$ channels are found in pancreatic $\beta$-cells, cardiac and smooth muscles. $\mathrm{K}_{\text {ATP }}$ channel blockers are used to treat DM and openers are used to treat angina and hypertension (Ghasemi et al., 2007; Gribble \& Reimann, 2003). Two genes for sulphonylurea receptors (SUR) have been identified, encoding the proteins SUR1/Kir6.2 and SUR2/Kir6.2, which are expressed in different tissues. SUR1/Kir6.2 are predominantly found in pancreatic $\beta$-cells and neurons. Alternative splicing of SUR2/ Kir6.2 produces a cardiac muscle isoform (SUR2A/ Kir6.2) and a smooth muscle isoform (SUR2B/Kir6.2) (Gribble \& Reimann, 2003; Lebrun et al., 2008). Binding of $\mathrm{K}_{\text {ATP }}$ channel inhibitors to the SUR1/Kir6.2 causes closure of the $\mathrm{K}_{\text {AтP }}$ channels in the $\beta$-cell induces membrane depolarization and a further influx of $\mathrm{Ca}^{2+}$ through the voltage dependent $\mathrm{Ca}^{2+}$ channels leading to the release of insulin from pancreatic $\beta$-cells by exocytosis. $\mathrm{K}_{\text {ATP }}$ channels can be nonselectively blocked in pancreatic as well as nonpancreatic tissues by some sulfonylurea like glibenclamide; it causes hypertension as a side effect due to blocking of SUR2 while nateglinide specifically blocked SUR1/Kir6.2 channels with high affinities but SUR2A/Kir6.2 and SUR2B/Kir6.2 channels only with low affinity. So nateglinide do not produced hypertension as a side effect (Chachin et al., 2003). $\mathrm{K}_{\text {ATP }}$ channel openers targeting the pancreatic $\beta$-cell are used therapeutically to reduce insulin secretion. Agents such as nicorandil, cromakalim, diazoxide, which open SUR2B/ Kir6.2, $\mathrm{K}_{\text {ATP }}$ channels in vascular smooth muscle, by contrast, are increasingly used in the treatment of angina and hypertension, but it causes hyperglycaemia due to opening of SUR1/Kir6.2, as an adverse effect (Gribble \& Reimann, 2003; Szewczyk, 1997; Seino, 2003).

Modulation of $\mathrm{K}_{\text {ATP }}$ channel activity is an important therapeutic tool for the treatment of type $2 \mathrm{DM}$ and cardiovascular disease. Drugs have been developed which selectively inhibit $\mathrm{K}_{\text {ATP }}$ channels in pancreatic $\beta$-cells, or open those in vascular smooth muscles and 
cardiac muscles. We need a single drug entity to treat diabetic hypertension that can lower blood glucose along with blood pressure.

Some herbal medicines like garlic are used both in diabetes as well as hypertension, acts as vasodilators by hyperpolarizing the membrane of normal vascular smooth muscle cells. The hyperpolarization in vascular smooth muscle occurs due to $\mathrm{K}^{+}$channel opener's activity (Siegel et al., 1998). Vasodilator activity of garlic is inhibited by glibenclamide, $\mathrm{K}^{+}$channel blocker (Ashraf et al., 2004). So these data support that garlic may act as a $\mathrm{K}^{+}$channel opener. Garlic also acts as an antidiabetic agent by enhancing glucose utilization, inhibition of intestinal absorption of glucose, and increasing the pancreatic secretion of insulin from existing $\beta$-cells or release from bound insulin (Eidi et al., 2006). Therefore an attempt was made to evaluate the antihypertensive as well as antidiabetic activity of allicin and confirm the SUR selectivity of allicin.

\section{Material and Methods}

Streptozotocin was purchased from Himedia Laboratory Ltd. (Mumbai). Dexamethasone, nateglinide and glibenclamide were procured from Zydus Cadila Healthcare Ltd. (Bangalore), Glenmark Pharmaceuticals Ltd. (Solan, Himachal Pradesh) and Cipla Pvt. Ltd. (Mumbai), respectively. All the other chemicals used for experimental purpose were of analytical reagent grades.

\section{Animals}

The albino rats (Wistar strain) of either sex weighing 150-200 g, bred in the animal house of Institute of Pharmaceutical Education and Research (Reg. No.535/02/a/CPCSEA/Jan2002), Wardha were used. All the animals were housed in polypropylene cages under controlled conditions of temperature $\left(22 \pm 2{ }^{\circ} \mathrm{C}\right)$, relative humidity $(50 \pm 5 \%)$ under controlled environment and illumination (12 h light-dark cycle), with free access to food (Lab diet) and water ad libitum. The animals were treated in accordance with the CPCSEA guidelines. The experimental protocol was approved by the Institute's Animal Ethics Committee with the approval number of 10/2009-10.

\section{Induction of hypertensive diabetes}

In the experimental rats, first diabetes was induced followed by induction of hypertension. Diabetes was induced in overnight fasted rats by freshly prepared $0.2 \mathrm{~mL}$ solution of streptozotocin $(50 \mathrm{mg} / \mathrm{kg}$, i.p. $)$ in $0.1 \mathrm{mM}$ sodium citrate buffer (Gupta \& Gupta, 2009). Hypertension was induced by subcutaneous injection of dexamethasone (10 $\mu \mathrm{g} / \mathrm{kg} /$ day, s.c.) in the evening (Ong et al., 2007; Zhang et al., 2004).

\section{Preparation of garlic aqueous extract}

The garlic (Allium sativum L., Amaryllidaceae) was obtained from Wardha region, identified and authenticated by Dr. Alka Chaturvedi, Department of Botany, Rashtrasant Tukadoji Maharaj Nagpur University, Nagpur with a voucher specimen of number 9803. Allicin containing garlic extract was prepared from $10 \mathrm{~g}$ of garlic cloves. The cloves were crushed with an electric vegetable crusher and the juice was poured into a sterile centrifuge tube and centrifuged at $5000 \mathrm{x} g$ for 10 $\mathrm{min}$ in order to separate the majority of the pulp from the supernatant liquid. The supernatant garlic extract (allicin containing) was either used immediately for activity or stored at $4{ }^{\circ} \mathrm{C}$ (Curtis et al., 2004), was relatively stable during the weeks of experiment protocol. Accordingly animals were administered with $8 \mathrm{mg} / \mathrm{kg}$ body weight of allicin (Elkayam et al., 2001).

\section{Determination of allicin in fresh garlic extract}

Allicin in the garlic extract $(10,20,30$ and $40 \mu \mathrm{L})$ was reacted with cysteine via the thiol-disulphide exchange reaction and the remaining cysteine was subsequently determined by reaction with Ellman's reagent 5,5'dithiobis-(2-nitrobenzoic acid) (DTNB) to produce the 2-nitro-5-thiobenzoate anion, absorbance was taken at wavelength $412 \mathrm{~nm}$. One mol of thiosulphinite reacts with 2 mol cysteine and since allicin makes up $60-80 \%$ of the thiosulphinates produced in garlic, multiplying the total thiosulphinate content by a factor of 0.7 gives the approximate allicin content (Curtis et al., 2004).

\section{Experimental design}

The experimental animals were randomized into five groups (six rats in each group). The experiment was conducted for a period of eight weeks. The drugs were administered by oral route in the form of $1 \%$ Acacia gum suspension. The allicin $(8 \mathrm{mg} / \mathrm{kg} / \mathrm{day})$ (Elkayam et al., 2001), nateglinide $(50 \mathrm{mg} / \mathrm{kg}$, twice in a day) (Kitahara et al., 2002) and glibenclamide (1 mg/kg/day) (Dewanjee et al., 2008) were administered in the animals of different groups as described below.

Group A: Normal control rats (C) were administrated $1 \mathrm{~mL}$ of $1 \%$ Acacia gum suspension for eight weeks.

Group B: Diabetic hypertensive control rats $\left(\mathrm{DH}_{0}\right)$ were administrated $1 \mathrm{~mL}$ of $1 \%$ Acacia gum suspension for eight weeks.

Group C: Diabetic hypertensive rats $\left(\mathrm{DH}_{1}\right)$ were administrated allicin $(8 \mathrm{mg} / \mathrm{kg} /$ day $)$ orally and nateglinide $(50 \mathrm{mg} / \mathrm{kg}$, twice in a day) in $1 \%$ Acacia gum suspension 
for eight weeks.

Group D: Diabetic hypertensive rats $\left(\mathrm{DH}_{2}\right)$ were administrated allicin $(8 \mathrm{mg} / \mathrm{kg} /$ day $)$ orally and glibenclamide $(1 \mathrm{mg} / \mathrm{kg} /$ day $)$ in $1 \%$ Acacia gum suspension for eight weeks.

Group E: Diabetic hypertensive rats $\left(\mathrm{DH}_{3}\right)$ were administrated allicin $(8 \mathrm{mg} / \mathrm{kg} /$ day $)$ orally daily $1 \%$ Acacia gum suspension for eight weeks.

\section{Measurement of blood glucose level}

Fasting serum glucose of each animal was measured every week by using a commercially available kit (One touch ultra, Johnson \& Johnson) based on glucose oxidase method (Eidi et al., 2006).

\section{Estimation of systolic blood pressure (SBP)}

SBP measurements were recorded weekly by the same investigator, between 10 am and 12 noon, using the integrated BIOPAC and NIBP 200A system. The animal is placed in the restrainer (animal holder) leaving the tail outside and adjusted to the position where the animal has limited movements. The restrainer is placed in heating chamber and heated up to $32^{\circ} \mathrm{C}$. BSL PRO software is used for recording of SBP, prior to starting the measurement the basic software setup is done and IR SENSORS are calibrated. IR SENSOR is then connected to the tail of the animal inside the restrainer. After the required setup and calibration of IR SENSORS, SBP was recorded.

Estimation of body weight, food intake and water intake

The body weight, food and water intake of the rats of each group were measured weekly up to eight weeks of the drugs treatment.

\section{Statistical analysis}

Statistical analysis was carried out by one-way analysis of variance (ANOVA) followed by Dunnett's multiple comparison test. All the values were expressed as mean \pm SEM. The results of all groups of animals were compared with control group results. A $p<0.05$ was considered to be statistically significant.

\section{Results}

Quantification of allicin from fresh garlic aqueous extract

Garlic extracts contained $12.8 \mathrm{mg}$ allicin/mL of the fresh garlic aqueous extract.

Effect of $\mathrm{K}^{+}$channel modulators on blood glucose level in diabetic hypertensive rats

As shown in Table 1, there was significant increase in the blood glucose level in $\mathrm{DH}_{0}$ (hypertensive diabetic) group when compared with $\mathrm{C}$ (normal control) group $\left({ }^{*} p<0.001\right)$. Blood glucose level was significantly $\left({ }^{*} p<0.001\right)$ decreased in $\mathrm{DH}_{1}$ (allicin+nateglinide), $\mathrm{DH}_{2}$ (allicin+glibenclamide) and $\mathrm{DH}_{3}$ (allicin treated) groups as compared to $\mathrm{DH}_{0}$ group.

\section{Effect of $\mathrm{K}^{+}$channel modulators on SBP in diabetic} hypertensive rats

Table 2, shows that SBP significantly $(* * p<0.001)$ increased in $\mathrm{DH}_{0}$ (Diabetic hypertensive control) when compared with normal control group. SBP of $\mathrm{DH}_{1}$ (allicin nateglinide treated) and $\mathrm{DH}_{3}$ (allicin treated) groups were found to be significantly $(* * p<0.001)$ decreased when compared with $\mathrm{DH}_{0}$ group and SBP of $\mathrm{DH}_{2}$ (allicin+glibenclamide treated) group was less significantly decreased $\left({ }^{*} p<0.01\right)$ in SBP when compared with $\mathrm{DH}_{0}$ group.

\section{Effect of $K^{+}$channel modulators on body weight}

There were significant $(* * * p<0.001)$ decrease

Table 1. Effect of $\mathrm{K}^{+}$channel modulators on blood glucose level in diabetic hypertensive rats.

\begin{tabular}{lccccccccc}
\hline \multirow{2}{*}{ Group(s) } & \multicolumn{7}{c}{ Blood glucose level $(\mathrm{mg} / \mathrm{dL})$} \\
\cline { 2 - 10 } & 0 week & $1^{\text {st }}$ week & $2^{\text {nd }}$ week & $3^{\text {rd }}$ week & $4^{\text {th }}$ week & $5^{\text {th }}$ week & $6^{\text {th }}$ week & $7^{\text {th }}$ week & $8^{\text {th }}$ week \\
\hline $\mathrm{C}$ & $88.67 \pm 3.91$ & $91.17 \pm 1.79$ & $94.83 \pm 1.64$ & $96 \pm 2.6$ & $100 \pm 3.39$ & $101 \pm 2.06$ & $97 \pm 1.62$ & $96 \pm 2.6$ & $96 \pm 2.17$ \\
$\mathrm{DH}_{0}$ & $321.5 \pm 33.7^{*}$ & $367.2 \pm 28.3^{*}$ & $406.5 \pm 29.4^{*}$ & $441.5 \pm 26.7^{*}$ & $497.5 \pm 25.3^{*}$ & $530.66 \pm 23.27^{*}$ & $546.3 \pm 20.8^{*}$ & $568.6 \pm 16.3^{*}$ & $588.1 \pm 8.96^{*}$ \\
$\mathrm{DH}_{1}$ & $310.8 \pm 31.93^{*}$ & $169.3 \pm 9.32^{*}$ & $147.0 \pm 6.80^{*}$ & $130.1 \pm 5.87^{*}$ & $115.8 \pm 4.20^{*}$ & $104.50 \pm 3.45^{*}$ & $97.33 \pm 1.89^{*}$ & $92.83 \pm 1.49^{*}$ & $94.33 \pm 2.12^{*}$ \\
$\mathrm{DH}_{2}$ & $343.5 \pm 23.86^{*}$ & $164.2 \pm 5.65^{*}$ & $142.8 \pm 5.02^{*}$ & $125.6 \pm 3.12^{*}$ & $112.8 \pm 2.76^{*}$ & $103.66 \pm 2.04^{*}$ & $93.66 \pm 2.13^{*}$ & $90.16 \pm 1.81^{*}$ & $88.83 \pm 1.70^{*}$ \\
$\mathrm{DH}_{3}$ & $326.8 \pm 26.39^{*}$ & $183.2 \pm 7.61^{*}$ & $163.6 \pm 6.43^{*}$ & $146.6 \pm 5.03^{*}$ & $130.3 \pm 4.06^{*}$ & $122.16 \pm 2.50^{*}$ & $116.0 \pm 2.64^{*}$ & $112.8 \pm 2.18^{*}$ & $111.0 \pm 1.86^{*}$ \\
\hline
\end{tabular}

Values are expressed as mean \pm SEM. $(\mathrm{n}=6)$, One way ANOVA followed by Dunnett's multiple comparison test $\left({ }^{*} p<0.001\right)$. For statistical analysis,

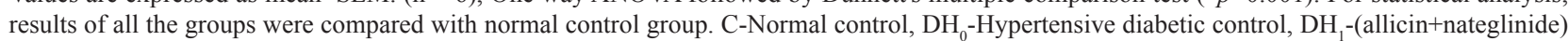
treated, $\mathrm{DH}_{2}$-(allicin+glibenclamide) treated, $\mathrm{DH}_{3}$-allicin treated. 
Table 2. Effect of $\mathrm{K}^{+}$channel modulators on systolic blood pressure (SBP) in diabetic hypertensive rats.

\begin{tabular}{lccccccccc}
\hline \multirow{2}{*}{ Group(s) } & \multicolumn{7}{c}{ Systolic blood pressure $(\mathrm{mmHg})$} \\
\cline { 2 - 9 } & 0 week & $1^{\text {st }}$ week & $2^{\text {nd }}$ week & $3^{\text {rd }}$ week & $4^{\text {th }}$ week & $5^{\text {th }}$ week & $6^{\text {th }}$ week & $7^{\text {th }}$ week & $8^{\text {th }}$ week \\
\hline $\mathrm{C}$ & $109.5 \pm 2.52$ & $108.66 \pm 1.56$ & $105.00 \pm 2.09$ & $103.00 \pm 1.21$ & $103.83 \pm 1.66$ & $103.83 \pm 2.57$ & $103.16 \pm 2.68$ & $103.83 \pm 3.17$ & $104.16 \pm 2.90$ \\
$\mathrm{DH}_{0}$ & $113.5 \pm 2.3^{* *}$ & $121.16 \pm 2.08^{* *}$ & $125.83 \pm 2.02^{* *}$ & $130.33 \pm 2.15^{* *}$ & $133.16 \pm 2.34^{* *}$ & $137.50 \pm 2.21^{* *}$ & $141.00 \pm 1.57^{* *}$ & $142.50 \pm 1.43^{* *}$ & $143.33 \pm 1.94^{* *}$ \\
$\mathrm{DH}_{1}$ & $107.3 \pm 2.13^{* *}$ & $111.83 \pm 2.15^{* *}$ & $110.83 \pm 2.15^{* *}$ & $106.83 \pm 2.08^{* *}$ & $104.33 \pm 1.87^{* *}$ & $107.83 \pm 0.87^{* *}$ & $105.5 \pm 0.99^{* *}$ & $100.66 \pm 0.84^{* *}$ & $106.00 \pm 0.84^{* *}$ \\
$\mathrm{DH}_{2}$ & $111.6 \pm 2.5$ & $113.33 \pm 2.88$ & $116.33 \pm 2.76$ & $120.33 \pm 1.89^{*}$ & $123.83 \pm 2.54^{*}$ & $124.16 \pm 2.21^{*}$ & $127.83 \pm 1.74^{*}$ & $130.83 \pm 1.01^{*}$ & $133.33 \pm 0.95^{*}$ \\
$\mathrm{DH}_{3}$ & $109.5 \pm 1.76$ & $115.16 \pm 2.67^{* *}$ & $119.66 \pm 0.89^{* *}$ & $119.33 \pm 2.32^{* *}$ & $117.51 \pm 2.10^{* *}$ & $117.5 \pm 0.98^{* *}$ & $116.3 \pm 1.89^{* *}$ & $116.5 \pm 0.76^{* *}$ & $116.16 \pm 0.8^{* *}$ \\
\hline
\end{tabular}

Values are expressed as mean \pm SEM. $(\mathrm{n}=6)$, One way ANOVA followed by Dunnett's Multiple Comparison test $\left({ }^{*} p<0.01 ; * * p<0.001\right)$. For statistical analysis, results of all the groups were compared with normal control group. Remaining legends are same as that of Table 1.

Table 3. Effect of $\mathrm{K}^{+}$channel modulators on body weight, water intake and food intake in diabetic hypertensive rats.

\begin{tabular}{lccc}
\hline Group(s) & Body weight $(\mathrm{g})$ & Food intake $(\mathrm{g} /$ day $)$ & Water intake $(\mathrm{mL} /$ day $)$ \\
\hline C & $174.5 \pm 6.32$ & $12.56 \pm 1.6$ & $21.40 \pm 1.13$ \\
DH0 & $135.3 \pm 9.21^{* * *}$ & $21.6 \pm 2.45^{* *}$ & $32.53 \pm 3.46^{* *}$ \\
DH1 & $161.8 \pm 5.84$ & $15.10 \pm 2.1$ & $27.73 \pm 2.86^{*}$ \\
DH2 & $168.43 \pm 3.92$ & $15.89 \pm 1.62$ & $28.31 \pm 2.25^{*}$ \\
DH3 & $159.37 \pm 7.36$ & $17.21 \pm 2.23$ & $30.68 \pm 2.94^{* *}$ \\
\hline
\end{tabular}

Values are expressed as Mean \pm SEM. $(\mathrm{n}=6)$, One way ANOVA followed by Dunnett's Multiple Comparison test $(* p<0.05 ; * * p<0.01 ; * * * p<0.001)$.

For statistical analysis, results of all the groups were compared with normal control group. Remaining legends are same as that of Table 1.

in the body weight was found in $\mathrm{DH}_{0}$ when compared to normal control group; and body weight of $\mathrm{DH}_{1}$ and $\mathrm{DH}_{2}$ (garlic + glibenclamide treated) groups were not significantly decrease from that of normal control group (Table 3).

\section{Effect of $K+$ channel modulators on water intake}

The present study shows, there were significantly $\left({ }^{* *} p<0.01\right)$ increased in water intake was found in $\mathrm{DH}_{0}$ (Diabetic hypertensive control) and $\mathrm{DH}_{3}$ groups when compared with normal control group and less significant increased water intake in $\mathrm{DH}_{1}$ and $\mathrm{DH}_{2}$ groups $\left({ }^{*} p<0.05\right)$ when compared to normal control group (Table 3 ).

\section{Effect of $K$ channel modulators on food intake}

$\mathrm{DH}_{0}$ group animals shows significant $(* * p<0.01)$ increased in food intake, while group shows no significant increased in food intake when compared with normal control group (Table 3).

\section{Discussion}

This study presents evidence that $\mathrm{K}^{+}$channel modulators can reduce the severity of diabetes induced hypertension because it acts as antidiabetic as well as antihypertensive agent i.e. $\mathrm{K}_{\mathrm{ATP}}$ channel opener acts as vasodilator and blocker acts as an antidiabetic agent. Modulation of $\mathrm{K}_{\text {ATP }}$ channel activity is an important therapeutic tool for the treatment of diabetic hypertension to avoid the adverse effects. Drugs have been developed which selectively inhibit $\mathrm{K}_{\mathrm{ATP}}$ channels in pancreatic $\beta$-cells or open those in vascular smooth muscles. This tissue selectivity is due to the expression of different types of sulphonylurea receptor (SUR1 or SUR2). So the drug used in the treatment of diabetic hypertension must have antidiabetic as well as antihypertensive activity.

Allicin shows potent antidiabetic activity as shown in Table 1. It has been reported that the garlic may affect the insulin secretion from $\beta$-cells, release of bound insulin or increase of insulin sensitivity (El-Demerdash et al., 2005). Allicin is the active component of garlic, responsible for enhancing serum insulin activity duo to free SH-group. On the other hand, antioxidative property of garlic might be another reason of its beneficial effect on diabetes (Shariatzadeh et al., 2008). Furthermore, it is also suggested that garlic might enhance glucose utilization because it significantly decreases the blood glucose level. It may be due to restoration of delayed insulin response or due to inhibition of intestinal absorption of glucose. This could be due to potentiating of the insulin by release from bound insulin (Eidi et al., 2006; Thomson et al., 2007).

The experimental rats of diabetic hypertensive groups i.e. $\mathrm{DH}_{1}$ (allicin+nateglinide treated) and $\mathrm{DH}_{2}$ (allicin+glibenclamide treated) shows potent antidiabetic activity, while rats of $\mathrm{DH}_{3}$ (allicin) treated group shows less significant antidiabetic activity when compared with $\mathrm{DH}_{1}$ and $\mathrm{DH}_{2}$ groups (Table 1). It may be because when 
allicin is given in combination with antidiabetic drugs, it shows the additive antidiabetic effect. Although earlier studies shown that garlic has a relaxant effect on vascular smooth muscle, which appears to be mediated through endothelium by increasing NO production (Ashraf et al., 2005; Oztiirk et al., 1994) some studies suggested that garlic extract might have value as ACE inhibitor to prevent hypertension (Hosseini et al., 2007; Sharifi et al., 2003). Antioxidant as well as antidiabetic effect of garlic (El-Demerdash et al., 2005; Shariatzadeh et al., 2008; Drobiova et al., 2009) might be responsible for antihypertensive effect because oxidative stress is major cause of hypertension in diabetic patient (De Champlain et al., 2004; Ceriello, 2008; Drobiova et al., 2009).

In the present study, a significant reduction in SBP, probable reason for this might be allicin hyperpolarized the cell membrane and relaxed the vascular strips concentration-dependently as a $\mathrm{K}^{+}$channel opener activity (Siegel et al., 1998; Ashraf et al., 2004; Sharifi et al., 2003). $\mathrm{DH}_{1}$ group (allicin+nateglinide treated) shows more potent antihypertensive activity when compared to $\mathrm{DH}_{2}$ (allicin+glibenclamide treated) group (Table 2). It is known that glibenclamide causes hypertension due to blocking of SUR2 (blood vessel) (Seino, 2003). Nateglinide has high affinity to pancreatic SUR1/Kir6.2 channels and very less affinity for blood vessel receptors SUR2A/Kir6.2, so blockade of SUR1/ Kir6.2 channels by nateglinide produces antidiabetic effect but not hypertension as a side effect due to free SUR2A/Kir6.2 receptors (Chachin et al., 2003). It means that when combination of nateglinide and allicin is given, allicin is free to bind on SUR2 receptor as opener causing vasodilation while glibenclamide blocks both SUR1 as well as SUR2, causing vasoconstriction.

Results of the present study may suggest that allicin does not act on SUR1 receptor. If allicin had acted on SUR1 receptors as an opener then it should have decreased insulin release and increased blood glucose level, which is not the case. It actually shows in result that there is no rise blood glucose level in $\mathrm{DH}_{3}$ group (Table 1). These data support that allicin may acts as SUR2 opener.

There was decrease in body weight in $\mathrm{DH}_{0}$ (diabetic hypertensive control) group. The reduction in body weight was more prominent in $\mathrm{DH}_{0}$ group (Table 3 ). Dehydration and loss of body weight have been associated with DM. In diabetic rats, increased food consumption and decreased body weight were observed. This indicates the polyphagic condition and loss of weight due to excessive breakdown of tissue proteins. The decrease in body weight in diabetic rats could be due to dehydration and catabolism of fats and proteins. Increased catabolic reactions leading to muscle wasting might also be the cause for the reduced weight gain by diabetic rats (Rajagopal \& Sasikala, 2008). Also hypertension was induced by dexamethasone, it causes decrease in body weight and food intake (Jahng et al., 2008; Carlos \& Salaman, 1991). This results in a loss of both fat and lean mass, leading to a significant $(* * p<0.001)$ reduction in total body weight in $\mathrm{DH}_{0}$ (diabetic hypertensive control) group.

We also recorded changes in water and food intake. $\mathrm{DH}_{0}$ group showed significant $(* * p<0.01)$ increase in food and water intake as compared to normal control group animals. In addition there was significant $\left({ }^{* *} p<0.01\right)$ increase in water intake in $\mathrm{DH}_{3}$ group while $\mathrm{DH}_{1}$ and $\mathrm{DH}_{2}$ groups showed less significant $\left({ }^{*} p<0.05\right)$ increase in water intake (Table 3$)$. It is well known that in diabetic condition there is an increase in osmolarity that induces thirst by stimulating thirst center in hypothalamus, causing increased water intake and hyperphagia which is followed by polydipsia. Also it may be due to hypothalamic neuropeptide Y (NPY) because previous study reported that concentrations of hypothalamic NPY in diabetic rats were consistently higher than those found in normal control rats, elevated concentrations of NPY, a very potent central stimulant of eating and drinking, may mediate the hyperphagia and polydipsia characteristic of diabetes (Williams et al., 1988; Sipols et al., 1995). Insulin deficiency in diabetes leads to increased hypothalamic AMPK activity, which contributes to the development of diabetic hyperphagia (Namkoong et al., 2005).

Oral administration of garlic extract and antidiabetic drugs for eight weeks to diabetic rats improved body weight and decreased their food consumption and water intake. This could be due to a better control of the hyperglycemic state in the diabetic hypertensive rats. Decreased Blood glucose could improve body weight in diabetic hypertensive rats.

\section{Conclusion}

Diabetes induced hypertension is the most severe complication of present scenario and there is no particular treatment for diabetic hypertension. Considering the literature and the results of our study, allicin may be effective in the treatment of diabetic hypertension. This study may reveal the possible mechanism for antihypertensive activity of allicin by selective opening of SUR2. Furthermore study required to confirm the SUR selectivity of allicin.

\section{References}

Aminot-Gilchrist DV, Anderson HD 2004. Insulin resistance associated cardiovascular disease: potential benefits of conjugated linoleic acid. Am J Clin Nutr 79: 1159S$1163 \mathrm{~S}$.

Ashraf MZ, Hussain ME, Fahim M 2004. Endothelium mediated 
vasorelaxant response of garlic in isolated rat aorta: role of nitric oxide. J Ethnopharmacol 90: 5-9.

Ashraf MZ, Hussain ME, Fahim M 2005. Antiatherosclerotic effects of dietary supplementations of garlic and turmeric: Restoration of endothelial function in rats. Life Sci 77: 837-857.

Carlos R, Salaman P 1991. Dexamethasone inhibits food intake suppression induced by low doses of interleukin-1 $\beta$ administered intracerebroventricularly. Brain Res Bull 27: 737-738.

Ceriello A 2008. Possible role of oxidative stress in the pathogenesis of hypertension. Diabetes Care 31: S181S184.

Chachin M, Yamada M, Fujita A, Matsuoka T, Matsushita K, Kurachi Y 2003. Nateglinide, a D-phenylalanine derivative lacking either a sulfonylurea or benzamido moiety, specifically inhibits pancreatic $\beta$-cell type KATP channels. J Pharmacol Exp Ther 304: 1025-1032.

Curtis H, Noll U, Stormann J, Slusarenko AJ 2004. Broadspectrum activity of the volatile phytoanticipin allicin in extracts of garlic (Allium sativum L.) against plant pathogenic bacteria, fungi and Oomycetes. Physiol Mol Plant P 65: 79-89.

De Champlain J, Wu R, Girouard H, Karas M, Midaoui AEL, Laplante MA, Wu L 2004. Oxidative stress in hypertension. Clin Exp Hypertens 26: 593-601.

Dewanjee S, Bose SK, Sahu R, Mandal SC 2008. Antidiabetic effect of matured fruits of Diospyros peregrina in alloxan-induced diabetic rats. Int J Green Pharm 2: 9599.

Drobiova H, Thomson M, Al-Qattan K, Peltonen-Shalaby R, Al-Amin Z, Ali M 2009. Garlic increases antioxidant levels in diabetic and hypertensive rats determined by a modified peroxidase method. Evid-based Compl Alt 2011: 1-8.

Eidi A, Eidi M, Esmaeili E 2006. Antidiabetic effect of garlic (Allium sativum L.) in normal and streptozotocininduced diabetic rats. Phytomedicine 13: 624-629.

El-Demerdash FM, Yousef MI, El-Naga NIA 2005. Biochemical study on the hypoglycemic effects of onion and garlic in alloxan-induced diabetic rats. Food Chem Toxicol 43: 57-63.

Elkayam A, Mirelman D, Peleg E, Wilchek M, Miron T, Rabinkov A, Sadetzki S, Rosenthal T 2001. The effects of allicin and enalapril in fructose-induced hyperinsulinemic hyperlipidemic hypertensive rats. $\mathrm{Am}$ J Hypertens 14: 377-381.

Ghasemi M, Sadeghipour H, Asadi S, Dehpour AR 2007. Timedependent alteration in cromakalim-induced relaxation of corpus cavernosum from streptozocin-induced diabetic rats. Life Sci 81: 960-969.

Gribble FM, Reimann F 2003. KATP channel pharmacology in the pancreas and the cardiovascular system. Int Congr Ser 1253: 279-287.

Gupta R, Gupta RS 2009. Effect of Pterocarpus marsupium in streptozotocin induced hyperglycaemic state in rats: comparison with glibenclamide. Diabetol Croat 38: 3945.

Hosseini M, Shafiee SM, Baluchnejadmojarad T 2007. Garlic extract reduces serum angiotensin converting enzyme (ACE) activity in nondiabetic and streptozotocindiabetic rats. Pathophysiology 14: 109-112.

Jahng JW, Kim NY, Ryu V, Yoo SB, Kim BT, Kang DW, Lee JH 2008. Dexamethasone reduces food intake, weight gain and the hypothalamic 5-HT concentration and increases plasma leptin in rats. Eur J Pharmacol 581: 64-70.

Kitahara Y, Miura K, Takesue K, Mine T, Wada R, Uchida Y, Ito $\mathrm{S}$, Yagihashi S 2002. Decreased blood glucose excursion by nateglinide ameliorated neuropathic changes in Goto-Kakizaki rats, an animal model of non-obese type 2 diabetes. Metabolism 51: 1452-1457.

Lebrun P, Becker B, Morel N, Ghisdal P, Antoine M, Tullio P, Pirotte B 2008. KATP channel openers: Tissue selectivity of original 3-alkylaminopyrido- and 3 alkylaminobenzothiadiazine 1,1-dioxides. Biochem Pharmacol 75: 468-475.

Moore DJ, Gregory JM, Kumah-Crystal YA, Simmons JH 2009. Mitigating micro- and macro-vascular complications of diabetes beginning in adolescence. Vasc Health Risk Manag 5: 1015-1031.

Namkoong C, Kim S, Jang PG, Han SM, Park HS, Koh EH, Lee WL, Kim JY, Park IS, Park JY, Lee KU 2005. Enhanced hypothalamic AMP-activated protein kinase activity contributes to hyperphagia in diabetic rats. Diabetes 54 : 63-68.

Ong SLH, Vickers JJ, Zhang Y, McKenzie K, Walsh CE, Whitworth JA 2007. Role of xanthine oxidase in dexamethasone-induced hypertension in rats. Clin Exp Pharmacol P 34: 517-519.

Oztiirk Y, Aydm S, Kogar M, Can Baqer KH 1994. Endotheliumdependent and independent effects of garlic on rat aorta. J Ethnopharmacol 44: 109-116.

Rajagopal K, Sasikala K 2008. Antihyperglycaemic and antihyperlipidaemic effects of Nymphaea stellata in alloxan-induced diabetic rats. Singap Med J 49: 137141.

Seino S 2003. Physiology and pathophysiology of KATP channels in the pancreas and cardiovascular system. $J$ Diabetes Complicat 17: 2-5.

Shariatzadeh SMA, Mehranjani MS, Mahmoodi M, Abnosi MH, Momeni HR, Dezfulian AR, Noori M 2008. Effects of garlic (Allium sativum) on blood sugar and nephropathy in diabetic rats. J Biol Sci 8: 1316-1321.

Sharifi AM, Darabi R, Akbarloo N 2003. Investigation of antihypertensive mechanism of garlic in $2 \mathrm{~K} 1 \mathrm{C}$ hypertensive rat. J Ethnopharmacol 86: 219-224.

Shin MJ, Chung N 2009. Increased arterial stiffness is associated with reduced plasma levels of $\beta$-carotene in treated hypertensive patients with type 2 diabetes mellitus, Nutrition. Nutr Metab Cardiovas 19: e9-e11. 
Siegel G, Nuck R, Schnalke F, Michel F 1998. Molecular evidence for phytopharmacological $\mathrm{K}+$ channel opening by garlic in human vascular smooth muscle cell membranes. Phytother Res 12: S149-S151.

Sipols AJ, Baskin DG, Schwartz MW 1995. Effect of intracerebroventricular insulin infusion on diabetic hyperphagia and hypothalamic neuropeptide gene expression. Diabetes 44: 147-51.

Sydow K, Mondon CE, Cooke JP 2005. Insulin resistance: potential role of the endogenous nitric oxide synthase inhibitor ADMA. Vasc Med 10: S35-S43.

Szewczyk A 1997. Intracellular targets for antidiabetic sulfonylureas and potassium channel openers. Biochem Pharmacol 54: 961-965.

Thomson M, Al-Amin ZM, Al-Qattan KK, Shaban LH, Ali M 2007. Anti-diabetic and hypolipidaemic properties of garlic (Allium sativum) in streptozotocin-induced diabetic rats. Int J Diabetes Metab 15: 108-115.

Wilhelm B, Weber MM, Kreisselmeier HP, Kugler M, Ries C, Pfutzner A, Kann PH, Forst T 2007. Endothelial function and arterial stiffness in uncomplicated type 1 diabetes and healthy controls and the impact of insulin on these parameters during an euglycemic clamp. J Diabetes $S c i$ Technol 1: 582-589.

Williams G, Steel JH, Cardoso H, Ghatei MA, Lee YC, Gill JS, Burrin JM, Polak JM, Bloom SR 1988. Increased hypothalamic neuropeptide $\mathrm{Y}$ concentrations in diabetic rat. Diabetes 37: 763-772.

Zhang Y, Croft KD, Mori TA, Schyvens CG, McKenzie KUS, Whitworth JA2004. The antioxidant tempol prevents and partially reverses dexamethasone-induced hypertension in the rat. Am J Hypertens 17: 260-265.

\section{*Correspondence}

Harikesh Dubey

Institute of Pharmaceutical Education and Research Wardha-442 001(MS), India

Tel.: +919312649997

Fax: +91 7152241684 . 